\section{FOREIGN BODY (BONE FRAGMENTS) IN THE BRONCHUS}

\section{TWO CASES TREATED EXPECTANTLY}

NEWELL BLY BURNS, A.B., M.D.

Assistant Superintendent and Physician, Nortl Reading (Mass.) State Salnatorium; Instructor in Pulmonary Diseases, Tufts College Medical School

NORTH WILMINGTON, MASS.

The aspiration of a foreign body into the bronchus is by no means a rare occurrence. The two cases reported herewith could not be called extraordinary instances. But the value of the experience lay in the failure to give due credit to the suspicion that a forcign body in the bronchus might be responsible for the intense disease reaction which subsequently arose in the lung.

Jach patient, an adult, inspired a piece of bone into a branch of the right bronchus. Secondary lung processes were well developed before the patients were scen at the sanatoritm. They were both treated expectantly with varying diagnoses until the bone fragments were spontaneously expelled. Then, with rapid recovcry taking place, the diagnoses for the first time became clear.

What might have been done is speculative; but a discussion of the possibilities, anticipating similar future experience, seems worth while because the expectant treatment as carried out in the two cases cited was far from satisfactory.

In earlier years the expectant treatment was practiced with the hope that the patient would bring up the foreign body by coughing. Kuhn ${ }^{1}$ collected reports of 374 cases, and the hoped for result occurred in only eighty-three. Garrè̃ states that the expectant treatment, with luck, may bring about inflammatory softening in the vicinity and may make the foreign body mobile again so that later it will be expectorated; on the other hand, we shall by this means expose many patients to the danger of serious pulmonary lesions with their less favorable prognosis.

Pneumonotomy has a dark record in Tuffier's $s^{3}$ eleven cases, resulting fatally in four, and successfully in two, and without the foreign body being found in five. (iarrè ${ }^{4}$ recommends this operation only if the foreign body has penetrated far into the periphery of the lung or when it is wedged into a branch of the third degree; and then it is indicated only when bronchoscopy promises no more hope of success, and furthermore only when the Roentgen ray accurately ascertains the position of the foreign body. Halstead ${ }^{6}$ found that with the use of bronchoscopy the trachea and bronchial tree down to the third subdivision of the bronchus are as open to ocular inspection as is the interior of the nose through the nasal speculum.

Discussing Tuffier's figures, Killian ${ }^{\circ}$ believed that the seriousness of these data called emphatically for furthering the Killian method of bronchoscopy.

Killian, ${ }^{7}$ in 1907, reported thirty-one cases in which the forcign body consisted of a piece of bone and which was observed through the medium of bronchoscopy.

1. Kuhn, cited by Latlam and English: $\Lambda$ System of Treatmont, $1915, \mathbf{3}, 803$

2. Garré, Karl, and Quincke, Heinrich, Surgery of the Lung, 1913, p. 228 .

3. Tuffier, cited by Killian, Gustay: Ztschr. f. Ohrenh., 55, 334.

4. Garrè and Quincke: Surgery of the Lung, p. 231.

5. Halsteid, Thomas H.: Tr. $X_{m}$. Laryngol., Rihinol. and Otol. Soc. 1909, $15,399$.

6. Killian: Ztschr. f. Ohrenh., 1908, $55,334$.

7. Killian: The Treatment of Forcign Bodies in the Respiratory $\mathbf{1 3}, 73$.
He had six such cases himself, and in every case he was successful in removing the piece of bone. While it appeared important to remove the inspired bone fragment as soon as possible, he found that three quarters of his cases were old ones.

With the development of direct bronchoscopy it would now scem a serious fault to make merely the cliagnosis of lung abscess, bronchiectasis, or lung gangrene when there is even the least suggestion in the patient's history of the aspiration of a foreign body. Lord" states that "foreign bodies should be suspected in all cases in which there is circumscribed bronchopneumonia, bronchiectasis, alsscess or gangrene of uncertain origin, and especially when the right lower lobe is involved." Of great importance in diagnosis is the use of the bronchoscope."

The lung disturbances in our two cases were located in the inferior lobes on the right side, the common side. Garre' found that the right side was usually elected. in a ratio of $100: 78$, because of the shorter right bronchus with its steeper course and somewhat larger lumen. Foreign bodies are therefore more easily inhaled into the right bronchus.

\section{REPORT OF CASES}

CAss: 1.-J. A. S., mant, aged 56, Nov. 29, 1911, was eating some pork, and was about to put his hand to his mouth to take out a piece of bone when he started to laugh. The piece of bone was inspired. He coughed hard for two hours. There was no pain or strcaked sputum. Nothing much happened for the next two weeks except that he felt some shortness of breath on exertion. Then cough and expectoration hegan. He continued at his work, that of stationary engineer and lireman. About one month after the accident, expectoration increased in amount. The patient had to sleep in a chair in a semirecumbent position. He could lie only flat on the stomach, cough being persistent if he tried to lic on his back. There was irregular vesperal fever and malaise during January and February. He had poor appetite because on cating solid food he would congh and vomit. The weight cleclined from 145 to 127 pounds in four months; March 18, 1912, he was obliged to give up work on account of weakness. Congh would come on quite suddenly following slight exertion, and several times daily and nightly he would raise a quantity of thick, foul-smelling sputum. He complained of "heart weakness," and wanted to sit still, fearing the slightest move. The sputum was examined several times during March at the sanatorium and always was negative for tubercle bacilli.

On March 25, 1912, the patient raised about 1 teaspoonful of hlood following a severe coughing fit. Soon afterward he conghed again, and the piece of bone landed on his tongue. On examination this fragment appeared to be roughly of culbical form. There was a small hooklike projection at one corner which, with handling, soon broke off. The composition was of spongy and cortical substance. The dimensions of the larger fragment were 15 by 10 by $11 \mathrm{~mm}$. The detached smaller segment was about 3 by $1 \mathrm{~mm}$.

For the next two or three days after expectorating this bone, the patient suffered considerable pain in the lung at a point about opposite the fifth rib just at the right of the sternum. It felt "like a boil coming to a head." The pain stopped on the third day when the patient suddenly expectorated several cupfuls of very foul, putrid, ycllowish sputum.

After this event there was a rapid and steady improvement in the patient's condition. Cough and expectoration ceased. June 1, 1912, he was able to return to work. He regained all the weight lost before the end of the year. He has worked stenclily up to this time, and is now in excellent condition, atthough he complained occasionally of "heart weakness."

A month or so after the trouble began, the patient squght medical advice. The common diagnosis appears to have been

8. Lord, F. T.: Disenses of the Bronchi, Lungs, and Pleura, p. 34.

9. Lord: Diseases of the Bronchi Lungs and Pleura, p. 35.
10. Ciarre and $Q$ unincke: Surgery of the Lung, pp. 20.21. 
"bronchitis." The patient was not satislied with this opinion, since his cough "came on too quickly." He was examined live or six times by as many physicians. The latter evidently gave little credit to the patient's statement regarding the inspired piece of bone, and one told him that he would surely have coughed it up long before.

The paticnt was seen by a consultant at the sanatoriun, March 30, 1912. The lung signs were those of lung abscess and associated bronchicctasis in the right lower lobes. The roentgenogram taken shortly afterward showed the absess cavity in the right inferior lobe near the root of the lung with considerable surrounding infiltration.

CAsE 2.-S. C., woman, aged 37, marricd, almitted to the sanatorium, April 20, 1916, was eating, Nov. 30, 1915, when a piece of lamb bone slipped down her throat and was inspired when she started to talk. There was a history of immediate cough and shortness of breath. During the five months' interval there developed malaise, weakness, severe cough and expectoration, loss of appetite, and loss of weight to the extent of 15 pounds. Two small hemoptyses had occurred. In liebruary, 1916, she gave birth to a child. On aclmission to the sanatorium, examination showed lung disturbance pretty well limited to the lower right lobes. The apexes were clear and also the entire left lung. The lower two thircls of the right thorax was practically immobile and was flat on percussion. The sharp demarcation at the thirel interspace front from good resonance to flatness was extraordinary. In the midback, bronchial breathing was heard with moist râles diminishing on cough, while the breath sounds were absent at the base. Fremitus was increased over this whole area.

There were vesperal fever and rapicl pulse rate. The sputum, 8 ounces per twenty-four hours, was negative for tuhercle bacili on admission, and in all subsequent examinations. Specimens were put through the shaking machine, antiformin preparations, and guinea-pigs. Urine examination revealed the presence of a chronic interstitial nephritis. Bloorl count revealed 22,000 white blood cells and 3,200,000 red blood cells.

This patient remained a bed case in the ward about all summer with fever, scvere cough and expectoration. Pain in the right sirle of "a scalding nature" was complained of. Her indispositions showed acute exacerbations with high fever, attendant rapid pulse rate and prostration. A feeling of suffocation was prominent. Fluic or pus being suspected at the base of the right lung, an attempted paracentesis was carried out with negative result.

Sept. 6,1916, not quite ten months after the aspiration of the forcign horly, the patient conghed up two pieces of bone. The larger fragment was of rough triangular form and measured 19 by 7 hy $8 \mathrm{~mm}$. Two of the angles were blunt, and the smaller fragment fitted approximately to one of these. The third angle was sharp. There appeared to be no recent cleavages other than the one to which the smaller fragment iitted. In composition the bone was cortical and spongy. The smaller fragment was only a spicule about 1 by $3 \mathrm{~mm}$. in dimensions. Soon after the patient had brought up this bone her symptoms began to clear up. Oct. 14, 1916 she was discharged from the sanatorium against advice. She has since continned to improve in spite of the poor home surroundings into which she went.

\section{COMMEN'T}

Killian ${ }^{11}$ states that cubical bodies are more difficult to remove. Bruenings devised a sharp hook forceps for this purpose. The pieces as a rule are flat in shape, 14 by $15 \mathrm{~mm}$. long and 8 by $9 \mathrm{~mm}$. wide, lying with their long diameter corresponding to the axis of the bronchus.

In Case 2, roentgenoscopy was not performed. It is perhaps needless to state that had there been opportunity for a roentgenogram at the time of the patient's admission to the sanatorium, much valuable informa-

11. Killian: The Treatment of loreign Bodies in the Respiratory Tract and Esophagus, Tr. Am. Laryngol., Rhinol. and Otol. Soc., 1907 13, 74 . tion would have been gained and there would have been less need of guesswork.

It is admitted ${ }^{H}$ that the Roentgen ray is less valuable for the actual demonstration of bone and ivory substance than for metallic foreign bodies in the bronchi, a positive result being obtained among forty of the former sort in only four.

Garrè $^{12}$ states that while there is a shadow cast by the aspirated piece of bone, it is generally not sufficiently large or intense to differentiate from other parts of the skeleton. After a while the surrounding infiltration and the formation of cicatrices or abscesses will give the necessary information.

Killian $^{13}$ concluded that without bronchoscopy the presence and nature of the foreign body could not always be ascertained. The illness was often considered only an obstinate case of bronchitis. In many a slowly developed suppuration of the lung of uncertain origin finally a foreign body is discovered.

In America the use of the bronchoscope has been successful in the extraction of foreign bodies from the bronchi. ${ }^{14}$ Yankauer $^{15}$ was obliged to have three roentgenograms taken before finding an indistinct shadow in the region of the left bronchus, attributable to an inspired prune stone which was extracted by the use of the bronchoscope.

Chevalier Jackson'16 states that the bronchoscopic removal of foreign bodes from the bronchi bloodlessly through the mouth has 96 per cent. successful results. Of 482 cases of aspirated foreign bodies, only four were recorded in which an upper lobe bronchus was invaded. Jackson's case was one of these four.

The contraindications are few, ${ }^{17}$ namely, aortic aneurysm and severe cardiac decompensation.

The published descriptions of this good work, and especially of Killian's six cases, ${ }^{7}$ in each of which it piece of bone was observed and eventually removed by bronchoscopy, furnish marvelous examples of the cleverest technic. The comparison between this method of treatment and the expectant treatment as experienced in our two cases has seemed to be worthy of general attention.

12. Garrè and Quincke: Surgery of the Lung, p. 218.

13. Killian: Zischr. f. Obrenh., $55,115.116$.

14. Jackson, Chevalier: The Dilatition of Bronchial Strictures, TuE JoURnal, A. M. A., Sept. 21, 1912, p. 1123.

15. Yankauer: Tr. Am. Laryngol,, Rhinol. and Otol. Soc., 1911, 17, 308.

16. Jackson, Chevalier: Tr. Am. Laryngol,, Rhinol, ind Otol, Soc., $1915, \mathbf{2 1}, 241$.

17. Lord: Discases of the Bronchi, Lungs and l'leura, p. 37

A Night and Day Camp.-The St. Louis Tuberculosis Society, according to the Journal of the Outdoor Life (April, 1917), has established what is called a Night and Day Camp, said to be the only preventorium for adults in the United States, and one of the few in the world. It is designed as a home for self-supporting girls over 14 years of age who have to stop work because of ill health. No cases of tuberculosis arc admitted, but it is a place where girls who are threatened with tuberculosis may go for convalescence from an attack of some disease, or where one who is worn out and nervous may rest and recuperate. The features of the institution are rest, outdoor life and good food. There are no charges, the camp being supported by the tuberculosis society, from the sale of Red Cross seals and otherwise. Since February, 1913, when the camp was started, it has taken care of 182 girls, of whom 160 have been discharged. The average stay at the camp has been three months and twenty-eight days, the average gain in weight of the girls has been 11 pounds and 14 ounces, and the average cost per day per patient has been 74 cents. 